\title{
PAMIĘĆ KULTUROWA A ZMIANY W KRAJOBRAZIE MIASTA ANALIZA OBCHODÓW ROCZNICOWYCH LOKACJI OLSZTYNA W ŚWIETLE KONCEPCJI ALEIDY I JANA ASSMANNÓW*
}

Zagadnienie pamięci rozpatrywanej $\mathrm{w}$ wymiarze społecznym $\mathrm{w}$ ostatnich kilkudziesięciu latach stało się jednym $z$ najszerzej dyskutowanych przez przedstawicieli różnych nauk humanistycznych ${ }^{1}$. Ten wzrost zainteresowania tematyką nie tylko zwrócił uwagę na wielowymiarowość i złożoność zjawiska, ale też zaowocował pojawieniem się wielu nowych koncepcji teoretycznych i związanych z nimi perspektyw badawczych, reprezentujących często bardzo odmienne spojrzenia na całą problematykę.

W polskim dyskursie humanistycznym najczęściej przywoływane są klasyczne już propozycje autorów piszących po francusku i angielsku ${ }^{2}$. Cytowani są zarówno prekursor badań nad pamięcią określaną dziś jako

\section{Adres do korespondencji: m-karkowska@wp.pl}

* Artykuł jest zmienionym fragmentem rozprawy doktorskiej „Upamiętnianie przeszłości w perspektywie Aleidy i Jana Assmannów teorii pamięci kulturowej (Analiza obchodów rocznicowych mieszkańców Olsztyna w latach 1945-2006)", napisanej pod kierunkiem prof. dr hab. Joanny Kurczewskiej, złożonej w Szkole Nauk Społecznych.

1 W literaturze przedmiotu najczęściej ostatnio przywoływaną definicją pamięci rozpatrywanej w aspekcie społecznym jest definicja pamięci zbiorowej, którą zaproponowała Barbara Szacka (2006, s. 44): „zbiorowa pamięć przeszłości to wyobrażenia przeszłości grupy własnej, konstruowane przez jednostki $z$ zapamiętywanych przez nie [...] informacji pochodzących $z$ różnych źródeł i docierających do nich różnymi kanałami. Są one rozumiane, selekcjonowane i przekształcane zgodnie $z$ własnymi standardami kulturowymi i przekonaniami światopoglądowymi $[\ldots] "$.

$2 \mathrm{~W}$ tym miejscu nie sposób przedstawić wszystkich propozycji teoretycznych i badawczych, dotyczących badania zjawiska pamięci w wymiarze społecznym, jakie pojawiły się $\mathrm{w}$ polskim dyskursie humanistycznym. Próbę taką podejmowali ostatnio między innymi: socjologowie tacy jak Barbara Szacka (2006) czy Piotr T. Kwiatkowski (2008), kulturoznawcy jak Bartosz Korzeniewski (2005, 2010), historycy jak Danuta Berlińska i Piotr Madajczyk (2008) czy Zofia Wóycicka (2009), a także badacze Holokaustu — jak Barbara Engelking-Boni (2001). 
zbiorowa Maurice Halbwachs, jak i autorzy tacy jak Pierre Nora, Paul Ricoeur, Jacques Le Goff oraz Jeffrey Olick, Michael Oakeshott, Kerwin Lee Klein czy Peter Burke, Paul Connerton, Benedict Anderson, Frank Ankersmit.

Propozycje autorów niemieckojęzycznych zajmujących się tą tematyką jeszcze do niedawna były przywoływane zdecydowanie rzadziej. W ostatnich latach zmieniło się to - coraz częściej są one nie tylko cytowane (przykładem mogą być tezy Haralda Welzera czy Otto Gerharda Oexele), ale też wykorzystywane w polskich badaniach ${ }^{3}$. Szczególną rolę zaczyna odgrywać koncepcja pamięci kulturowej Aleidy i Jana Assmannów, która - choć skłania do stawiania pytań ${ }^{4}$ - zaczyna być $z$ powodzeniem stosowana na gruncie badań polskich.

Jak pokazały rozprawy przedstawicieli różnych dyscyplin akademickich ${ }^{5}$, przyjęcie perspektywy Assmannów nie tylko daje możliwość podjęcia wielu zagadnień trudnych do rozpatrzenia w ramach tradycyjnych analiz historycznych czy socjologicznych, ale też pozwala oprzeć badania na konkretnym modelu teoretycznym opatrzonym użytecznym instrumentarium badawczym. Interesować mnie będzie to, jakie możliwości daje zastosowanie perspektywy Assmannów do badań nad lokalnym wymiarem pamięci określanej przez nich jako kulturowa? Jakie ograniczenia wiążą się z przyjęciem tej koncepcji jako podstawy teoretycznej na gruncie polskich badań nad lokalnością? ${ }^{6}$ Podczas poszukiwania odpowiedzi sięgnę do analiz pamięci kulturowej powojennych mieszkańców Olsztyna - społeczności będącej depozytariuszem wielokulturowego i złożonego dziedzictwa, doświadczonej koniecznością dokonania istotnych zmian w postrzeganiu przeszłości w wyniku zasadniczych przekształceń ustrojowych.

3 Wynika to zapewne $z$ większej dostępności publikacji badaczy niemieckich, jak i z coraz większego wpływu, jaki na współczesny dyskurs pamięci zbiorowej mają ich prace. Szerzej na ten temat pisze Jeffrey Olick w tekście „Collective memory”: A Memoir and Prospect, „Memory Studies” 2008, t. 1, s. 23-29.

4 Warto tu wspomnieć choćby wątpliwości Petera Novicka wyrażone w: Comments on Aleida Assmann's Lecture („GHI Bulletin” 2007, nr 40, s. 27-31) czy uwagi Astrid Erll (2009).

$5 \mathrm{Na}$ język polski została przetłumaczona tylko jedna książka Jana Assmanna (2008) oraz kilka artykułów obojga autorów (Assmann A. 2009a, 2009b, 2009c; Assmann J. 2003, 2009). Perspektywę Assmannów polskim czytelnikom przybliżyli Robert Traba (2008) i Magdalena Saryusz-Wolska (2009), którzy wykorzystali ją również w swoich analizach (np. Traba 2005, 2006; Saryusz-Wolska 2007), podobnie jak autorzy tacy jak Hubert Orłowski (np. 2004), Bartosz Korzeniewski (np. 2010), Jerzy Kałążny (2007) czy Rafał Żytyniec (2007), ale także Danuta Berlińska i Piotr Madajczyk (2008) czy Zofia Wóycicka (2009).

6 Tematyka pamięci zbiorowej rozpatrywana w odniesieniu do przypadków społeczności lokalnych od niedawna coraz częściej pojawia się w badaniach polskich. Wcześniej do rzadkości należały pulikacje, w których poświęcano więcej uwagi temu zagadnieniu, jak prace zbiorowe zatytułowane Oblicza lokalności pod redakcją Joanny Kurczewskiej (np. Kurczewska 2006). 
Najpierw należy wyjaśnić, czym w modelu Assmannów jest pamięć kulturowa. $\mathrm{W}$ ich publikacjach jest ona przedstawiana jako jeden $\mathrm{z}$ dwóch (obok pamięci komunikatywnej ${ }^{7}$ ) typów pamięci zbiorowej ${ }^{8}$.

„Pojęcie pamięci kulturowej — stwierdził Jan Assmann (2003, s. 15) jeszcze w latach osiemdziesiątych - skupia w sobie charakterystyczny dla każdej społeczności i epoki zasób ponownie używanych tekstów, wyobrażeń i rytuałów, w których pielęgnuje, stabilizuje i przekazuje ona wyobrażenie o samej sobie, podzielaną zbiorowo wiedzę przeważnie (choć niekoniecznie) o przeszłości, na której grupa opiera świadomość swojej jedności i swoistości".

W kolejnych latach koncepcja była rozwijana. W jednej ze swoich najważniejszych prac Pamięć kulturowa. Pismo, zapamiętywanie i polityczna tożsamość $w$ cywilizacjach starożytnych Jan Assmann (2008, s. 68) podkreślał, że pamięć kulturowa - w przeciwieństwie do pamięci komunikatywnej - opiera się na zinstytucjonalizowanej mnemotechnice. To zaś oznacza, iż tworzona jest „odgórnie", za pośrednictwem instytucji nadzorowanych przez szeroko rozumiane władze - najczęściej władze państwowe. Dopiero tak uformowany przekaz, zawierający zarówno określoną treść, jak i interpretację (inaczej sens w koncepcji Assmannów), jest prezentowany społeczności, która na tej podstawie może budować wspólnotę pamięci i wspólną tożsamość.

Aby wyjaśnić sposób odczytywania i oddziaływania tego przekazu, ale też jego zawartość, zasięg i formy, Assmannowie wprowadzili kategorię mediów pamięci. Media pamięci to w ich ujęciu wszelkie „nośniki” służące przekazywaniu treści i sensów pamięci kulturowej. Są one „materialnym substratem pamięci" (Assmann A. 2009b, s. 112). Ich rodzaje, funkcje i znaczenie opisywała Aleida Assmann (2009a, s. 171). Podkreślała, że mediami pamięci mogą być zarówno teksty, obrazy, pomniki, jak i krajobraz, rytuały, zwyczaje tworzące pewien zasób przekazów.

W poniższych rozważaniach skupię się jedynie na tych elementach owego substratu, które są usytuowane w przestrzeni miejskiej i tworząc tę przestrzeń pełnią rolę nośników treści kulturowych. Będą to nie tylko pomniki czy tablice pamiątkowe, ale też całe zespoły architektoniczne czy krajobrazy miejskie

7 Jan i Aleida Assmannowie w pracach $z$ lat osiemdziesiątych i dziewięćdziesiątych podkreślali, iż w modelu teoretycznym pamięci zbiorowej wyróżniają dwa, wzajemnie przenikające się i zazębiające typy pamięci: pamięć kulturową i pamięć komunikatywną. Pamięć komunikatywna to „pamięć dnia codziennego" - wspomnienia funkcjonujące w ramach grupy, dotyczące jej najbliższej przeszłości i doświadczeń, przekazywane w sposób niesformalizowany, w codziennych kontaktach. Jej przykładem może być pamięć pokoleniowa. Należy zaznaczyć, iż początkowo Jan Assmann oddzielał pamięć komunikatywną od pamięci kulturowej, wręcz przeciwstawiając je sobie, później jednak uznał je za dwa, wzajemnie od siebie zależne, wzajemnie na siebie oddziałujące typy pamięci.

8 Termin „pamięć zbiorowa” jest tu używany jako określenie nadrzędne dla zjawisk pamięci rozpatrywanych $\mathrm{w}$ aspekcie społecznym (w odróżnieniu od pamięci rozpatrywanej w aspekcie psychologicznym) i kategoria analityczna obejmująca pamięć kulturową i pamięć komunikatywną. 
zawierające przekazy dotyczące przeszłości Olsztyna. Przy ich wyborze kierowałam się znaczeniem dla formowania wyobrażeń o przeszłości. Istotne dla analizy będą też działania mające na celu na przykład przywrócenie dawnego wystroju wybranych obszarów miejskich, renowację elementów architektonicznych, wyeksponowanie niektórych budowli ${ }^{9}$, gdyż — zgodnie $z$ założeniami Assmannów - zmiany te odzwierciedlają nie tylko aktualny w danym czasie stosunek do przeszłości, ale też priorytety wspominania i cele upamiętniania przeszłości.

Należy zwrócić uwagę na jeszcze jedno zagadnienie dotyczące zmian i ciągłości przekazów mediów pamięci. Assmannowie w swoich pracach podkreślają, że choć sama treść przekazu może pozostać niezmienna, to jego odczytywanie i interpretacja mogą być bardzo odmienne $\mathrm{w}$ różnych momentach czasowych, w różnych warunkach. Dlatego dokonując analiz przekazów pamięci kulturowej widocznych w przestrzeni miejskiej Olsztyna, a także analizy interpretacji tych zmian, odwołam się do przykładów z dwóch momentów czasowych — z lat 1953 i 2003.

W obu przypadkach był to czas szczególny. Na rok 1953, uznawany za apogeum stalinizmu w Polsce, przypadł jubileusz sześćsetlecia miasta. Pół wieku później warunki polityczne, społeczne i gospodarcze były już zupełnie inne (Achremczyk, Ogrodziński 2003, 2006). W 2003 r. od zmiany ustrojowej minęło kilkanaście lat, w ciągu których w życie publiczne zostały wprowadzone mechanizmy demokratyczne i pojawiła się możliwość nieskrępowanej wypowiedzi. Nie pozostało to bez wpływu nie tylko na sposób interpretacji i upamiętnienia przeszłości miasta, ale też na obchody jubileuszu 650-lecia Olsztyna.

Obchody są tu kwestią kluczową. Zgodnie $z$ koncepcją Aleidy i Jana Assmannów powtarzalność, upamiętnianie i uświadamianie przeszłości należą do ważniejszych cech i celów pamięci kulturowej. Przybierają one postać różnego rodzaju cyklicznych uroczystości, które Jan Assmann określał jako działania ceremonialne, przekraczające sferę codzienności. Wówczas odtwarzane są „ustalone wcześniej formy przekazywania i uświadomienia sensu kulturowego".

W przypadku Olsztyna, miasta przynależącego w historii do państwa krzyżackiego, polskiego, pruskiego i niemieckiego, te cele i cechy pamięci kulturowej uwidoczniły się najwyraźniej właśnie w czasie obchodów rocznicowych nawiązujących do początków dziejów miasta. Dlatego stały się one podstawą analiz. Ponieważ trudno byłoby tu omówić całość zagadnienia, postaram się jedynie zwrócić uwagę na wybrane przykłady zmian w przestrzeni miejskiej stolicy Warmii, a także zmiany i ciągłości znaczeń przypisywanych wybranym jej elementom, będące przejawem pamięci kulturowej w obu wybranych momentach.

9 O zmianach w krajobrazie kulturowym Warmii i ich znaczeniu dla tożsamości społeczności lokalnych pisała m.in. Iwona Liżewska (Liżewska 2006, 2009; Liżewska, Knercer 2004). 
Odmienność przykładów, które dzieli półwiecze, wywołuje pytania dotyczące możliwości porównywania wydarzeń zachodzących $\mathrm{w}$ tak odmiennych warunkach. Mierzący się z tym problemem Assmannowie zaproponowali kategorię analityczną figur wspomnień ${ }^{10}$. Jan Assmann (2008, s. 53) — opierając się na koncepcji „obrazów pamięci” Maurice’a Halbwachsa - stwierdził, iż figury wspomnień to ukształtowane kulturowo i obowiązujące w grupie wyobrażenia przeszłości, niosące „prawdę ustaloną przez grupę, i przedstawioną w konkretnych formach wspomnień, osób, miejsc".

Figury wspomnień mają trzy charakterystyczne cechy: po pierwsze, konkretne odniesienie do przestrzeni i czasu, po drugie, odniesienie do grupy, po trzecie, rekonstruktywność lub rekonstruowalność (Rekonstruktivität). Odniesienie do określonego czasu i przestrzeni oznacza, że znaczenia symboliczne konkretnych figur wspomnień, związane $z$ nimi sensy nie są ustalone, trwałe czy stabilne, lecz mogą się zmieniać w zależności od warunków — ram odniesienia. Odniesienie do grupy wskazuje na to, iż są budowane właśnie przez grupę posiadającą własną tożsamość i kultywującą pamięć o swojej przeszłości. Rekonstruktywność oznacza zaś, że pamięć kulturowa opiera się wprawdzie na stałych figurach wspomnień i zasobach wiedzy, jednak „każda teraźniejszość zawłaszcza je, jednocześnie rozprawiając się z nimi, zachowując je i zmieniając" — interpretuje je na nowo (Assmann J. 2008, s. 56-57).

Kategoria figury wspomnień odnosi się więc nie tylko do konkretnych historycznych postaci, zjawisk czy wydarzeń (tak jak rozumieją je historycy), ale przede wszystkim do wyobrażeń, wspomnień o tych postaciach, zjawiskach czy wydarzeniach. Wspomnień funkcjonujących w określonym czasie, w określonym kontekście. Takie ujęcie zagadnienia pozwala porównywać nie same wydarzenia historyczne czy zjawiska, lecz sposób postrzegania tych zjawisk czy wydarzeń w różnych momentach czasowych.

Okazuje się to niezwykle istotne właśnie $\mathrm{w}$ przypadkach analizy pamięci zbiorowej społeczności zmuszonej modyfikować swoje wyobrażenia o przeszłości pod wpływem zmieniających się ram odniesienia. Pamięć kulturowa mieszkańców Olsztyna rozpatrywana w kontekście zmian, jakie zaszły w Polsce na przestrzeni półwiecza - od lat pięćdziesiątych XX wieku do początku kolejnego stulecia - jest przykładem wyjątkowo jaskrawym, dającym możliwość wykazania zalet i wad, możliwości i ograniczeń omawianej perspektywy.

$\mathrm{Na}$ początku analizie zostaną poddane najważniejsze ciągłości i zmiany w założeniach i wyobrażeniach o przeszłości Olsztyna w dwóch momentach czasowych, wyrażające się w zachowaniu wybranych elementów przestrzeni miejskiej lub jej przemianach. Następnie zajmę się wybranymi elementami

$10 \mathrm{~W}$ polskich przekładach prac Assmannów funkcjonuje też termin „figury pamięci” (Assmann J. 2008), jednak ze względu na występujacy w niemieckim dyskursie humanistycznym podział na $\mathrm{Ge}$ dächtnis (pamięć) i Erinnerung (wspomnienie) trafniejsze wydaje się użycie terminu „figura wspomnień" (Erinnerungsfiguren). 
architektonicznymi, na trwałe umieszczonymi w przestrzeni miejskiej, upamiętniającymi rocznicę lokacji miasta, takimi jak tablice pamiątkowe, pomniki. Przywołane zostaną też elementy czasowo wprowadzone $\mathrm{w}$ przestrzeń miasta (głównie w 2003 r.), mające przypominać o jubileuszu oraz tradycjach miasta, takie jak banery, plakaty czy materiały promujące miasto. Analiza tych ostatnich służyć ma przede wszystkim wskazaniu, jakie sensy w danym czasie były promowane i jak - zgodnie $z$ intencją organizatorów obchodów - powinny one być odczytywane. Pozwoli to na ukazanie przemian i ciągłości wizji przeszłości miasta, jej zawartości treściowej i interpretacji wybranych elementów w różnym czasie.

W analizie wyobrażeń o przeszłości Olsztyna pomocna jest koncepcja miasta jako palimpsestu. Kategoria palimpsestu (występująca w pracach przedstawicieli różnych dyscyplin akademickich ${ }^{11}$ ) pojawia się $\mathrm{w}$ wielu publikacjach Aleidy i Jana Assmannów, najczęściej podczas wyjaśniania procesów dominacji czy zastępowania jednych treści kulturowych drugimi bądź przemian sensów nadawanych poszczególnym pojęciom ${ }^{12}$. Palimpsest - jak przypomina Aleida Assmann (2007, s. 111 i nast.) - to rękopis sporządzony na pergaminie, z którego ostrożnie usunięto pierwotny tekst, by zastąpić go nowym. Pierwszy zapis dzięki odpowiednim środkom można jednak odszyfrować. Słowo „palimpsest” to także filologiczna metafora.

Miasto postrzegane jako palimpsest zyskuje trzy wymiary i może być rozpatrywane, po pierwsze, jako przestrzeń skupiająca historię; po drugie, jako rezultat powtarzalnych przeformułowań, przepisywania, osadzania; po trzecie, jako przykład różnorodnych warstw substancji miejskiej, pozostawionych przez żyjące $\mathrm{w}$ mieście kolejne pokolenia, prezentowanych jednocześnie $\mathrm{w}$ przestrzeni miejskiej, choć nie postrzeganych jako jednoczesne i obecne w świadomości mieszkańców w danym momencie.

Zastosowanie tej kategorii $\mathrm{w}$ badaniach nad zmianami i ciągłościami pamięci kulturowej, tak jak czynią to Assmannowie, pozwala prześledzić, w jaki sposób, w jakiej formie $\mathrm{w}$ dwóch momentach czasowych tkanka miasta odzwierciedlała wyobrażenia o jego przeszłości. Istotne okazały się tu nie tylko nowe elementy krajobrazu miasta, ale też interpretacje znaczeń poszczególnych budowli, ich przeznaczenie, sposób eksponowania i opisywania w danym czasie, kontekst, w jakim są rozpatrywane i przedstawiane, bo - jak zaznacza Aleida Assmann (1999, s. 330) - „Miejsce jest tym wszystkim, czego się w nim szuka, co się o nim wie, z czym się je łączy”.

\footnotetext{
11 Kategoria ta, kojarzona ze szkołą tartusko-moskiewską (Żyłko 2010), jest wykorzystywana zarówno przez kulturoznawców zajmujących się tematyką miasta (Rewers 1999), jak i przez badaczy szeroko pojmowanej tematyki pamięci (Huyssen 2007).

12 To zagadnienie przedstawia Jan Assmann (2005, s. 121), między innymi omawiając pojęcie kanonu.
} 
Ta ostatnia teza znajduje uzasadnienie w świetle zmian przestrzeni miejskiej Olsztyna w ciągu półwiecza rozpatrywanych w kontekście zmian i ciągłości pamięci kulturowej.

W 1953 r. w krajobrazie miasta nie umieszczono żadnych nowych, trwałych znaków czy materialnych pamiątek nawiązujących do jubileuszu 600-lecia wydania aktu lokacyjnego grodu nad Łyną. Nie oznacza to jednak, iż brak działań nie odzwierciedlał bieżącego stanu pamięci kulturowej. Na podstawie zachowanych materiałów dotyczących jubileuszu można przypuszczać, iż taka forma uczczenia przeszłości po prostu nie była brana pod uwagę przez władze miasta czy regionu, na co wpływ miała z pewnością sytuacja polityczna, gospodarcza i społeczna mieszkańców Olsztyna, wciąż doświadczających skutków niedawno zakończonej wojny (Tomkiewicz 2003). Niechęć do świętowania rocznicy wydania aktu lokacyjnego mogła też wynikać z faktu, iż dokument powstał z inicjatywy i na polecenie kapituły warmińskiej, a gród leżał wówczas w obrębie państwa krzyżackiego, na terenie dominium biskupiego.

Ten brak działań upamiętniających ze strony władz miasta wiązał się najwyraźniej z nowymi wytycznymi państwowej ideologii ${ }^{13}$, nakazującymi promowanie nowej wizji przeszłości. Wizja ta widoczna była w zmianach, jakie w latach pięćdziesiątych zaszły na obszarze Starego Miasta stolicy Warmii. Wymuszona zniszczeniami wojennymi konieczność odbudowy lub przebudowy miasta nałożyła się wówczas na reorganizację przestrzeni miejskiej zgodną z obowiązującą nową filozofią architektoniczną. Nie chodziło jednak o wpisanie w zastaną przestrzeń nowych elementów, lecz o niemal całkowitą jej przemianę. Sytuację tę celnie scharakteryzował Andrzej Rzempołuch, pisząc o zmianach w architekturze $z$ lat 1950-1955:

„Odtworzenie substancji architektonicznej to na gruncie olsztyńskim problem przede wszystkim ideologiczny, a w najmniejszym stopniu konserwatorski. [...] Aby zrozumieć istotę i plastyczny, zewnętrzny wyraz tej odbudowy, trzeba sięgnąć do podłoża wszelkich działań składających się na zagospodarowanie ziem nazwanych wówczas i później Odzyskanymi. Z takiego określenia przedmiotu działań wynika przede wszystkim kwestia tożsamości. Można powiedzieć, że architektura Starego Miasta w Olsztynie została «odgermanizowana», można stwierdzić, że "repolonizowana» - skutek jest jeden. Rynek po odbudowie w niewielkim stopniu przypomina ten sprzed wojny, ulice Prosta i Staromiejska są zupełnie nowe. [...] W tamtym czasie nie trzeba było specjalnie podkreślać, że następuje rekonstrukcja tożsamości przedrozbiorowej już nie samego Olsztyna, który perłą baroku nigdy przecież nie był, lecz w symboliczny sposób całej polskiej Warmii" (Rzempołuch 2004, s. 147).

Można więc powiedzieć, sięgając do pojęcia miasta jako palimpsestu, iż w tym wypadku starano się nie tyle osadzić nowe elementy w starym tekście,

13 Szeroko na ten temat pisali m.in. Marcin Zaremba (2005), Marcin Kula (2004), Rafał Stobiecki (2007). 
ile napisać go niemal na nowo. Istotne przy tym było usunięcie tych fragmentów, które odnosiły się do konkretnych okresów z dziejów Olsztyna - czasu niemieckiej bądź pruskiej przynależności państwowej.

Taką hipotezę potwierdza też dobór i sposób eksponowania wybranych treści w trakcie obchodów 600-lecia Olsztyna. Jedyną instytucją, która podjęła się upamiętnienia jubileuszu, był olsztyński Oddział Polskiego Towarzystwa Historycznego (PTH). Członkowie olsztyńskiego PTH na czele z Emilią Sukertową-Biedrawiną (przygotowującą obchody we współpracy między innymi z Tadeuszem Grygierem) zorganizowali poświęconą historii grodu nad Łyną sesję naukową, w której udział wzięli przedstawiciele Zarządu Głównego PTH i środowisk uniwersyteckich ${ }^{14}$. Była to najważniejsza forma uczczenia rocznicy.

Spotkanie zostało zorganizowane w salach olsztyńskiego zamku. Zamieszczane w prasie zdjęcia i szkice ilustrujące obchody 600-lecia miasta i jego historię najczęściej przedstawiały właśnie tę warownię. Jednak nie ona stała się symbolem historii Olsztyna. W trakcie tych uroczystości i w relacjach prasowych $\mathrm{z}$ ich przebiegu podkreślano, iż najważniejszą postacią $\mathrm{w}$ dziejach miasta był Mikołaj Kopernik, Olsztyn zaś określano przede wszystkim jako „gród Kopernika”. Astronom kreowany był na symbol polskości i patriotyzmu, „myślący po polsku" uczony i dobry gospodarz powierzonych mu - jako kanonikowi warmińskiemu - dóbr, walczący z Zakonem Krzyżackim „bojownik o wolność i polskość" (Borowik 1953, s. 1). Co więcej, jak wynika z prasy wydawanej w tamtym okresie, ważniejsze niż sam jubileusz miasta okazało się uczczenie kolejnej, 480 rocznicy urodzin Mikołaja Kopernika i 410 rocznicy jego śmierci. Rok 1953 został nawet ogłoszony Rokiem Kopernikowskim.

Ta hierarchia ważności miała zasadniczy wpływ na to, w jaki sposób mówiono o mieście. Zamek prezentowany był jako najważniejsza budowla oraz co wielokrotnie podkreślano - jako siedziba Mikołaja Kopernika. Wobec tego, w jakim świetle przedstawiany był sam astronom, a także starań o wykreowanie prowadzonej przez niego w 1521 r. obrony fortecy przed Krzyżakami na jedno $z$ kluczowych wydarzeń $w$ dziejach grodu nad Łyną, Zamek stawał się symbolem polskości miasta.

Pół wieku później znaczenia wiązane z zamkiem i Mikołajem Kopernikiem były inne.

Odwołując się do koncepcji Assmannów można powiedzieć, że choć postać i warownia w dalszym ciągu pełniły funkcję lokalnych figur wspomnień, to wiązane $z$ nimi sensy lokalnej pamięci kulturowej uległy zmianie. Zamek

14 Najważniejsze materiały dotyczące wydarzenia można znaleźć między innymi w Ośrodku Badań Naukowych im. W. Kętrzyńskiego w Olsztynie (Emilia Sukertowa-Biedrawina, Na 600-lecie Olsztyna (zarys historyczny) PTH-R 183) oraz w Archiwum Polskiej Akademii Nauk w Warszawie (m.in. Protokoty z zebrań członków i z zebrań zarządu PTH Oddziatu w Olsztynie, syg. II/209/3, II/209/4; Protokót z uroczystego posiedzenia Polskiego Towarzystwa Historycznego Oddział w Olsztynie poświęconego 600-letniej rocznicy powstania miasta Olsztyna, syg. II/209/3). 
wciąż przedstawiany był jako jedna z najważniejszych budowli miasta, ale już nie jedyny jego symbol i ostoja polskości miasta. W tym czasie eksponowane były także inne olsztyńskie zabytki, a zamek kreowany był przede wszystkim na ośrodek kulturalny i atrakcję turystyczną, budowlę dowodzącą jednocześnie „długiego trwania” miasta i jego istotnych funkcji jako warowni na przestrzeni wieków. Taki wizerunek miasta i zamku prezentowany był wielokrotnie w trakcie odbywających się uroczystości rocznicowych, a potwierdzać go miały wystawy, koncerty, a także publikacje rocznicowe.

Zmianie uległ też sposób przedstawiania Mikołaja Kopernika. Uczczono go, lecz już w zupełnie inny sposób niż przed pięćdziesięcioma laty. W związku z jubileuszem 650-lecia Olsztyna na terenie Starego Miasta umieszczono nową rzeźbę przedstawiającą Mikołaja Kopernika. Rzeźbę tę oglądać można dziś tuż przy moście prowadzącym do wejścia na zamek, obok kościoła ewangelickiego, u zbiegu ulic Zamkowej i Okopowej. Figura, nazywana „ławeczką z Kopernikiem", przedstawia astronoma spoglądającego na swoją dawną siedzibę, siedzącego na niewysokim murku, $\mathrm{z}$ modelem układu słonecznego w prawej dłoni i zwiniętym pergaminem w lewej. Na „Ławeczce” umieszczono napis „Mikołaj Kopernik", daty jego urodzin i śmierci oraz cytat $z$ jednego $z$ jego dzieł: „...dążeniem uczonego... jest szukanie we wszystkim prawdy..."

Odsłonięcie pomnika odbyło się po 650 latach od daty wystawienia przywileju lokacyjnego - 31 października 2003 r. - i było częścią głównych uroczystości jubileuszu miasta. Oficjalnie miejscy urzędnicy deklarowali, że nowa rzeźba miała być „formą uczczenia astronoma i pozostawienia w mieście trwałej pamiątki po jubileuszu", a także jedną z atrakcji turystycznych. Przy Koperniku można usiąść i zrobić pamiątkowe zdjęcie.

Ten pomnik Kopernika nie był pierwszym w przestrzeni miasta. Popiersie astronoma umieszczone na postumencie w parku nieopodal zamku można było oglądać od kilku dziesięcioleci. Pomysł wybudowania pomnika pojawił się w 1903 r., w czasie obchodów 550-lecia nadania Olsztynowi praw miejskich. Popiersie wykonał berliński rzeźbiarz Johannes Götz. Zostało odsłonięte w listopadzie 1916 r. z okazji 400-lecia przybycia astronoma do Olsztyna, niemal w tym samym miejscu, w którym stoi dziś „ławeczka z Kopernikiem”. W czasie wojny ukrywano je w piwnicy zamku, a w 1946 r. przeniesiono na skwer znajdujący się na tyłach warowni. Zdjęto wówczas niemiecki napis i umieszczono nową sentencję: „Obrońcy grodu olsztyńskiego przed najeźdźcą krzyżackim. Wielkiemu Polakowi Mikołajowi Kopernikowi - wdzięczni rodacy" 15.

Pomnik pozostał na swoim miejscu, jednak zdecydowanie stracił na znaczeniu. Popularność zyskała rzeźba usytuowana tuż przy wejściu do zamku.

15 Ilustracje i informacje dotyczące pomnika Mikołaja Kopernika w Olsztynie: z początku XX wieku (Grabowska 2003, s. 152), ponowne odsłonięcie pomnika z 27 października 1946 r. (Achremczyk, Ogrodziński 2003, s. 425-426 ); obecny wygląd pomnika (Czerwiński 2009, s. 65). Zob. także w.olsztyn.eu/fileadmin/katalogi_wydzialowe/kultura/wydawnictwa/symbole_pl.pdf. 
Co więcej okazało się, że to właśnie ta nowa forma zaprezentowania astronoma odzwierciedla aktualny sposób jego postrzegania przez mieszkańców Olsztyna. Kopernik, jak wynika z tekstów prasowych i popularnonaukowych, coraz rzadziej określany był jako „wielki Polak”, częściej zaś jako „najznamienitszy mieszkaniec miasta", znany na całym świecie uczony, którego dawna obecność w mieście jest powodem do dumy także dla współczesnych. Można więc powiedzieć, iż Kopernika symbolicznie „zdjęto z piedestału” znaczących bohaterów narodowych i umieszczono wśród mieszkańców miasta, wyznaczając nową rolę - osobistości promującej gród nad Łyną.

Inny wydźwięk niż w 1953 r. zyskały również uroczystości rocznicowe. Władze miasta jako ich główny organizator (a także pomysłodawcy i instytucje biorące udział w całym przedsięwzięciu) uznały, że jubileusz jest okazją nie tylko do uczczenia konkretnych osób związanych z miastem, ale także do wyeksponowania kilku obiektów budzących skojarzenia z przeszłością bądź cechami charakterystycznymi grodu nad Łyną, nie tylko zamku.

Jeden $z$ pomysłów, jakie pojawiły się w trakcie przygotowań do jubileuszu 650-lecia Olsztyna, zakładał pozostawienie w przestrzeni miejskiej trwałych śladów obchodów tej rocznicy. Ostatecznie zdecydowano o umieszczeniu na ścianach dwóch budynków pamiątkowych tablic.

Pierwsza $z$ nich znalazła się $w$ widocznym miejscu (na pierwszym piętrze) w budynku Nowego Ratusza - obecnej siedzibie władz lokalnych, czyli Urzędu Miasta. Pomysłodawcą i inicjatorem konkursu na wykonanie projektu tego „widocznego znaku jubileuszu” był Urząd Miasta. Zgodnie z regulaminem konkursu tablica miała zawisnąć na zewnętrznej lub wewnętrznej ścianie budynku zajmowanego przez władze miejskie, a jej odsłonięcie miało być częścią głównych uroczystości związanych z upamiętnieniem rocznicy lokacji Olsztyna. Władzom miejskim zależało przede wszystkim na podkreśleniu związku między przeszłością a teraźniejszością miasta. Tablica miała nawiązywać do dwóch dat: daty wydania przywileju lokacyjnego dla Olsztyna i daty głównych obchodów jubileuszu w 2003 r. Te ujęte w regulaminie konkursu założenia zostały zrealizowane. Odlana $\mathrm{w}$ brązie tablica projektu E. Łagowskiego została uroczyście odsłonięta w dniu „urodzin miasta” - 31 października 2003 r. Przedstawia ona trzy budowle charakterystyczne dla architektury Olsztyna Zamek Olsztyński, Wysoką Bramę oraz Olsztyńskie Planetarium i Obserwatorium Astronomiczne. Całość wieńczy herb miasta i dwie wstęgi z datami: 31 października 1353 r. i 31 października 2003 r.

Nieco inny charakter i znacznie mniejsze rozmiary ma tablica umieszczona na ścianie średniowiecznej Wysokiej Bramy — jedynej ocalałej bramy miejskiej i jednego $z$ trzech najstarszych zabytków miasta (obok kościoła św. Jakuba i Zamku). Tablica ta, nosząca tytuł „Tarcze”, została wykonana przez Wiesława Karczmarka. Składa się z dwóch tarcz połączonych napisem „Olsztyn”. Na pierwszej odnotowano datę 31 października 1353 r. i umieszczono dwa elementy dawnego herbu miasta oraz elementy herbu kapituły warmińskiej. Są 
to stylizowane: półkrzyż, a obok niego wieża zamkowa (lub fragment bramy miejskiej) zwieńczona blankami. Na drugiej tarczy umieszczono wizerunek św. Jakuba, zgodny ze współczesną wersją herbu Olsztyna, a pod nim napis 31 października 2003 r. W 2003 r. przy okazji prac konserwatorskich przy murach obronnych miasta przeprowadzono rewaloryzację Górnej Bramy, powszechnie nazywanej Wysoką Bramą (Jasiński 2002, s. 9.). Budowla została wzbogacona o zaaranżowany fragment muru $z$ obronnym gankiem - to właśnie na nim umieszczono „Tarcze”.

Dobór miejsc przedstawianych na obu tablicach, jak i miejsc ich umieszczenia nie był przypadkowy. Zarówno Ratusz, jak i Wysoka Brama należą do najbardziej rozpoznawalnych miejsc w topografii miasta. Ich wymowa i skojarzenia, jakie budzą, tworzą istotny kontekst dla interpretacji treści zawartych $\mathrm{w}$ tablicach upamiętniających 650-lecie Olsztyna. Zestawienie obu budowli nieść ma znaczenie symboliczne, znane jeszcze z czasów pierwszej wojny światowej. W jednej z publikacji wydanych $\mathrm{w}$ roku jubileuszowym czytamy, że właśnie wtedy „został ustalony nadzwyczaj prosty kanon przedstawiania Olsztyna: nowy ratusz - zgodnie $z$ intencją władz - symbolizował nowe miasto; dla historycznego Olsztyna taką ikoną był zamek" (Rzempołuch 2003, s. 14).

Nie bez znaczenia było też wyeksponowanie budynku nowego ratusza. Ratusz, ukończony w 1926 r. ${ }^{16}$ (a więc w czasach, gdy Olsztyn leżał w granicach państwa niemieckiego), długo był kojarzony z pruskim dziedzictwem miasta ${ }^{17}$. Zgodnie z zamierzeniami władz na początku nowego tysiąclecia jego sylwetka miała nabrać nowej wymowy: wskazywać na długą historię miasta i sięgające daleko w przeszłość tradycje ${ }^{18}$. Kwestia pierwotnej „polskości” bądź „niemieckości" nowego ratusza utraciła ideologiczny wymiar. Ważniejsze okazało się przedstawienie go jako budowli symbolizującej bogate dziedzictwo miasta. W kategoriach koncepcji Assmannów można powiedzieć, że choć medium pamięci pozostało to samo, to nieść ma ze sobą już nowe treści i być interpretowane w nowy, odmienny sposób.

Oba przykłady upamiętnienia jubileuszu pokazują, iż inicjatorom tych przedsięwzięć zależało nie tylko na podkreśleniu czasu lokacji miasta, ale też na przypomnieniu jego długiej historii i odniesieniu się do współczesności.

Istotne okazały się zwłaszcza detale wskazujące na tradycję Olsztyna. W obu przypadkach pośrednio lub bezpośrednio nawiązano do czasów założenia miasta przez kapitułę warmińską oraz do czasów współczesnych. Takie skojarzenia

\footnotetext{
16 Prace budowlane zakończono zimą $1918 \mathrm{r}$.

17 Jak można przeczytać w informacji zamieszczonej w portalu miejskim na temat tej budowli: „pierwotny program ikonograficzny opowiadał o sukcesach oręża pruskiego $\mathrm{w}$ czasie pierwszej wojny światowej" (http://olsztyn.kei.pl/index.php?option=com_content\&task=view\&id=262\& Itemid=246). Szerzej zob. Piechocki 1994.

18 Dokumenty przechowywane przez Wydział Kultury, Promocji i Turystyki Urzędu Miasta Olsztyna, dotyczące konkursu na plakat upamiętniający jubileusz 650-lecia miasta.
} 
budzi zestawienie wizerunku św. Jakuba i powstałego w końcu lat siedemdziesiątych Olsztyńskiego Planetarium i Obserwatorium Astronomicznego upamiętniającego Mikołaja Kopernika.

Zmiany pamięci kulturowej mieszkańców miasta odzwierciedla także przywrócenie jednego z elementów powojennego wyglądu Wysokiej Bramy od strony Starego Ratusza, czyli wizerunku Matki Bożej z Dzieciątkiem ${ }^{19}$. Był to namalowany na drewnie obraz, który przez blisko sto lat wisiał w blendzie Wysokiej Bramy, a usunięty został w 1949 r., prawdopodobnie na polecenie ówczesnych władz ${ }^{20}$. W związku z jubileuszem Olsztyna postanowiono go przywrócić, choć w nieco zmienionej formie. Zdecydował o tym Komitet Honorowy obchodów 650-lecia miasta, a zaakceptował Wydział Kultury Urzędu Miasta. Ostatecznie w blendzie Wysokiej Bramy umieszczono mozaikę wykonaną w watykańskiej Fabricca di san Pietro, wzorowaną na obrazie Matki Bożej ze Stoczka Warmińskiego. Mozaikę poświęcił Jan Paweł II. Przedsięwzięcie zostało sfinansowane przez Kazimierza Krawczyka, szefa Katolickiego Stowarzyszenia Społeczno-Gospodarczego im. kard. Stanisława Hozjusza (Wysoka Brama..., 2003) ${ }^{21}$.

Na murze Wysokiej Bramy umieszczono także tablicę zawierającą następujący tekst:

Niech Maryja Królowa Pokoju strzeże bram Olsztyna i jego mieszkańców Jan Paweł II — Rzym 18 lutego 2004 A.D.

Mozaika jest darem papieża Jana Pawła II dla Olsztyna z okazji 650-lecia miasta

$\mathrm{Na}$ tablicy widnieją także dwa herby - herb Olsztyna przedstawiający św. Jakuba i herb papieski. Nad tablicą umieszczono niewielkie popiersie Jana Pawła II.

Całe przedsięwzięcie było niezwykle istotne dla olsztyńskiego duchowieństwa. Przywrócenie wizerunku Matki Bożej miało przede wszystkim wymiar symboliczny, jak stwierdził metropolita warmiński w wypowiedzi na temat obchodów 650-lecia założenia miasta:

„Jest to doskonała okazja, aby przywrócić wizerunek Matki Bożej w Wysokiej Bramie, która otwiera Stare Miasto, a który wisiał tam przez blisko 100 lat. [...] Stąd uważam, ze Wysoka Brama będąca furtą do Starego Miasta winna posiadać symbol religijny" (Piszcz 2003).

Zarówno w prasie codziennej, jak i w czasopismach katolickich podkreślano, iż przywrócenie wizerunku Matki Bożej miało być nawiązaniem do daw-

$19 \mathrm{~W}$ wielu publikacjach mowa jest o obrazie Matki Boskiej z Dzieciątkiem.

$20 \mathrm{~W}$ tym samym czasie podobny los spotkał także inne przedstawienia religijne, na przykład figurę Chrystusa trzymającego kulę ziemską. W 1949 r. figura ta, stojąca dotąd przy placu Trzech Krzyży, została przeniesiona na skwer przy kościele Najświętszego Serca Jezusowego.

${ }^{21} \mathrm{~W}$ projekt zaangażowali się między innymi proboszcz parafii św. Jakuba i arcybiskup metropolita warmiński ks. dr Edmund Piszcz, ale też prezydent Olsztyna Czesław Małkowski. Mozaika została przywieziona $z$ Włoch na początku marca i odsłonięta 29 kwietnia. 
nej tradycji (Kopiczko 2003, s. 4; Jasiński 2002, s. 9) i moralnym zadośćuczynieniem za decyzję władz z końca lat czterdziestych (Piszcz 2003). Zaznaczano też zaangażowanie papieża $\mathrm{w}$ obchody jubileuszu miasta, co podnosiło ich rangę.

Połączenie obchodów jubileuszu lokacji miasta $z$ wydarzeniem religijnym po 1989 r. jest stosunkowo często praktykowane. Podobny wymiar miała na przykład peregrynacja obrazu Matki Boskiej w Cudy Wielmożnej Pani Poznania zorganizowana w związku z obchodami 750-lecia lokacji Poznania, zakończona aktem zawierzenia miasta wizerunkowi Matki Bożej w 35 rocznicę koronacji obrazu, której przed poznańską katedrą dokonali prymas Stefan Wyszyński, kardynał Karol Wojtyła i abp Antoni Baraniak.

Ponowne wprowadzenie wątku tradycji chrześcijańskiej, katolickiej jako części tradycji miasta znalazło wyraz także w kolejnych zmianach w przestrzeni Olsztyna. Były one związane $z$ przypomnieniem i wykreowaniem na figurę wspomnień lokalnej pamięci kulturowej św. Jakuba. Święty Jakub Starszy stał się patronem grodu nad Łyną wraz z wydaniem w połowie XIV wieku aktu lokacyjnego. Jego postać znalazła się na niemal wszystkich przedstawieniach herbowych miasta. Jak ważny był on dla historii Olsztyna, świadczą liczne wizerunki apostoła, które do dziś znaleźć można na fasadach olsztyńskich budynków ${ }^{22}$.

W latach pięćdziesiątych postać ta wspominana była rzadko. Dokumenty powstałe $\mathrm{w}$ związku z uroczystym posiedzeniem PTH z okazji 600-lecia Olsztyna nie mówią też nic o tym, by w czasie uroczystości poruszano kwestię patronatu miasta. Do postaci św. Jakuba jako patrona Olsztyna rzadko odwoływano się także w artykułach prasowych nawiązujących do jubileuszu miasta, najwyżej zamieszczano krótką wzmiankę. Do postaci apostoła krótko nawiązali autorzy pracy Sześć wieków Olsztyna, pisząc o zmianach herbu miasta w ciągu wieków:

„Zachowane stare rysunki herbu przedstawiają pielgrzyma, utożsamianego ze św. Jakubem, trzymającego woreczek lub muszlę. Pielgrzym ten, ubrany w strój świecki, idzie polem lub stoi w pobliżu bramy miejskiej" (Wakar, Wolski 1956, s. 15).

Jak sugerują autorzy, aureola i stylizowana połowa krzyża zostały wprowadzone do herbu w czasach późniejszych, prawdopodobnie w XIX wieku. Teza ta została powtórzona w latach siedemdziesiątych przez Andrzeja Wakara (1971, s. 39), który postać przedstawioną na pieczęciach miejskich interpretuje jako wędrowca lub pielgrzyma utożsamianego ze św. Janem Ewangelistą lub św. Jakubem. Nie tylko pokazuje to, jak dalece starano się zatrzeć pamięć o religijnym wymiarze herbu Olsztyna, ale też jest przykładem zgodnego z propagowaną w połowie XX wieku ideologią sposobu interpretacji dawnych przedstawień.

Zdecydowanie inaczej o patronie Olsztyna mówiono pół wieku później. Postać św. Jakuba przypominana była po roku 1989 w różnych kontekstach

22 Znaczenie świętego i jego rolę w dziejach miasta w czasach średniowiecza i w okresie nowożytnym opisali między innymi Janusz Jasiński (2003, s. 5) czy Stanisław Piechocki (2004, s. 9). 
i przy okazji różnych uroczystości. Nowego znaczenia nabrała ona właśnie w trakcie jubileuszu 650-lecia miasta. Nie tylko odnowiono wówczas zwyczaj uroczystego obchodzenia dnia św. Jakuba, ale też zaprezentowano nowy herb i flagę miasta nawiązujące do jego patrona.

Jako element obchodów rocznicowych i jednocześnie trwały ślad po jubileuszu Olsztyna pozostała mozaika przedstawiająca herb miasta - św. Jakuba. Została ona umieszczona na placu przed Starym Ratuszem - jednym z większych placów olsztyńskiej Starówki. Jest to pochodzące z 1982 r. przedstawienie współczesnego herbu miasta, który nawiązuje do czternastowiecznego pierwowzoru. Widoczny jest na nim wizerunek św. Jakuba Starszego z typowymi dla tego świętego atrybutami.

Rok po obchodach 650-lecia Olsztyna na Targu Rybnym odsłonięto także pomnik św. Jakuba. Rzeźba przedstawiająca apostoła początkowo miała zostać umieszczona w blendzie, u wejścia na olsztyńskie Stare Miasto w Wysokiej Bramie, jednym z najstarszych budynków Olsztyna. Ostatecznie zrezygnowano $z$ tego pomysłu, głównie z powodów technicznych. Po przeróbkach umieszczono ją na postumencie i odsłonięto w czasie Dni Olsztyna, w dniu św. Jakuba ${ }^{23}$.

Wszystkie te zabiegi: umieszczenie przedstawień św. Jakuba w przestrzeni miejskiej, a zwłaszcza zmiana flagi i odniesienia do postaci patrona Olsztyna $\mathrm{w}$ jej barwach i elementach, pokazują, jak bardzo - w porównaniu z latami wcześniejszymi - zmieniły się sensy łączone $z$ patronem grodu nad Łyną i symboliczny wymiar postaci. Św. Jakub został włączony w system ideowy propagowany wśród mieszkańców Olsztyna; stał się figurą wspomnień niosącą informację o chrześcijańskich korzeniach miasta, założonego przez kościelną kapitułę.

Zapomnieć nie można także o konkatedrze św. Jakuba, jednej z dwóch najstarszych budowli w mieście (obok Wysokiej Bramy) i jednocześnie świątyni archidiecezji warmińskiej. W 1945 r., po przeniesieniu do Olsztyna siedziby diecezji warmińskiej, ten kościół parafialny zaczął pełnić funkcję kościoła prokatedralnego, a od $1973 \mathrm{r}$. stał się konkatedrą na równi z bazyliką fromborską. W 2003 r. został podniesiony przez Jana Pawła II do miana bazyliki mniejszej.

Wiele na temat treści i sensów pamięci kulturowej wiązanych $z$ tą budowlą i jej patronem rozpatrywanym jako figura wspomnień na początku XXI wieku mówią elementy czasowo umieszczone w przestrzeni Olsztyna w 2003 r. Jednym z nich był plakat miejski „650 lat Olsztyna”, mający rozpropagować jubileusz ${ }^{24}$.

\footnotetext{
${ }^{23}$ http://miasta.gazeta.pl/olsztyn/1,35187,2196013.html

${ }^{24} \mathrm{Na}$ wykonanie jego projektu konkurs ogłosił Urząd Miasta, który jednocześnie był fundatorem nagród. Zwycięzcą okazał się związany z Wydziałem Nauk Społecznych i Sztuki UWM w Olsztynie profesor Piotr Obarek, którego dwa projekty zostały nagrodzone i następnie wykorzystane w przedsięwzięciach mających na celu promocję miasta.
} 
Wiele mówi także praca opatrzona godłem „Ratusz”, której w konkursie przyznano II miejsce ${ }^{25}$. Jest to zestawienie fragmentów dwóch zabytków Olsztyna - wieży katedry św. Jakuba i wieży Nowego Ratusza. Na szczytach obu budynków umieszczono chorągiewki czy też plakietki z dwiema datami: 1353 na chorągiewce katedry św. Jakuba i 2003 na chorągiewce wieży Nowego Ratusza. Przedstawienie to zinterpretowano w następujący sposób:

„Do II nagrody wytypowano projekt opatrzony godłem «Ratusz», którego autor odwołuje się do sylwetek wież najbardziej znanych budowli stojących w naszym mieście. Tej najstarszej, gotyckiej wieży katedry św. Jakuba (patrona miasta) pochodzącej z XIV w. oraz młodej, liczącej zaledwie 87 lat neobarokowej wieży ratusza $\mathrm{z}$ początku XX w. Te dwie wieże to klamra spinająca dzieje miasta od jego zarania po czasy współczesne, dająca czytelny obraz wizualny..." (Protokół z posiedzenia..., 2003).

Dla komisji konkursowej istotne okazało się zatem zwłaszcza podkreślenie łączności przeszłości i teraźniejszości. O wadze tego przekazu świadczy jedna $z$ uwag komisji. Zaproponowała ona „zmianę kompozycyjną poprzez zbliżenie wieży katedralnej do wieży ratuszowej w celu ześrodkowania elementów symbolizujących historyczny upływ czasu". Wynika z tego, że dla komisji konkursowej niezwykle ważny był właśnie ten aspekt — symbolicznego przedstawienia długiej historii miasta. Odpowiadał też wspomnianej wcześniej, sięgającej do początków XX wieku, konwencji przedstawiania Olsztyna. Zauważyć należy, że w tym kontekście umieszczenie obok siebie na plakacie siedziby władz miejskich i symbolu władz kościelnych nie obrazuje stosunków między sferą świecką i religijną. Dla twórcy plakatu jubileuszowego i dla jury konkursu ważniejsza była „dawność” i średniowieczne korzenie świątyni, a zwłaszcza „najstarszej, gotyckiej wieży", co podkreśla też data lokacji miasta na chorągiewce umieszczonej na rysunku świątyni.

Jako symbolu długich tradycji miasta nie wybrano wizerunku olsztyńskiego Zamku, mimo iż to właśnie ta budowla była i jest uważana za symbol miasta ${ }^{26}$. Fakt ten uznać należy za niezwykle istotny w kontekście zmian pamięci kulturowej. Wskazuje on przede wszystkim na zmianę priorytetów tej pamięci i upamiętniania przeszłości. Sięga się już nie tylko po te elementy, które kojarzą się z Kopernikiem i polskością, ale też po te, które wyróżniają miasto - jak wielowiekowa, bogata historia i rola jako ośrodka religijnego.

Wskazuje na to choćby sposób, w jaki przedstawiano pół wieku wcześniej kościół św. Jakuba. W latach pięćdziesiątych w prasie, podobnie jak w pracach popularnonaukowych, jedynie sporadycznie wspominano o tej najstarszej

25 Komisja konkursowa postanowiła nie przyznać I i III miejsca uzasadniając swoją decyzję faktem, iż liczba i jakość nadesłanych plakatów nie spełniła oczekiwań organizatorów.

26 Sylwetka Zamku pojawiła się w logo miasta przygotowanym w związku z obchodami jubileuszu Olsztyna, umieszczanym na znaczkach, pocztówkach i plakatach. Logo to, po modyfikacji, nadal jest wykorzystywane przez Urząd Miasta. 
olsztyńskiej świątyni. Nie uczczono także w szczególny sposób - jak wynika z dostępnych relacji - ówczesnej rocznicy „sześćsetlecia grodu”. Obchodów jubileuszu miasta, którego założycielem była kapituła warmińska, nie odnotowano w oficjalnych publikacjach Kurii Biskupiej w Olsztynie, choć w „Warmińskich Wiadomościach Diecezjalnych" (1953-1954, s. 5) znalazła się informacja między innymi na temat kazania „O miłości Ojczyzny” w związku z obchodami Dziesięciolecia Polski Ludowej. Artykułów na temat rocznicy lokacji Olsztyna nie zamieszczono także w głównym wydaniu „Słowa Powszechnego”, a w jego lokalnym dodatku jedynie wspomniano o budowli i jej patronie.

Należy zwrócić uwagę na jeszcze jedną kwestię — sposób wyeksponowania (lub pomijania) tego aspektu przeszłości miasta, który wiąże się z jego wielokulturowością. Przykładów można by tu wskazać wiele (Liżewska 2006, 2009; Liżewska, Knercer 2004), skupię się jednak na przykładzie wplatania w pamięć kulturową mieszkańców Olsztyna pamięci o Erichu Mendelsohnie.

Ten urodzony w Olsztynie architekt zmarł w jubileuszowym roku 1953, co stało się powodem do przypomnienia jego sylwetki. Kilka artykułów na jego temat zamieszczono w „Głosie Olsztyńskim”. Z ich treści wynika, że autorom zależało przede wszystkim na przedstawieniu opisywanej postaci jako światowej sławy architekta związanego $z$ miastem. $Z$ innych źródeł można wnioskować, iż w owym okresie Mendelsohn uważany był za „żydowskiego architekta związanego z kulturą niemiecką" (np. Chłosta 2003).

W tekstach powstałych z okazji jubileuszu 650-lecia Olsztyna Mendelsohn opisywany był inaczej. Architekt został krótko przedstawiony w monografii Olsztyn 1353-2003 (Achremczyk, Ogrodziński 2003), wymieniono go jako jedną z najbardziej znanych i znaczących postaci Olsztyna, w rozdziale dotyczącym rozwoju przestrzennego miasta. 650-lecie miasta stało się też okazją do przypomnienia o miejscach związanych $z$ architektem. W prasie pojawiły się artykuły opisujące fatalny stan żydowskiego domu pogrzebowego ${ }^{27}$, jedynego projektu Mendelsohna zrealizowanego w Olsztynie. Jubileusz miasta miał stać się okolicznością sprzyjającą renowacji zabytku. Sam budynek został opisany jako „jeden $z$ ostatnich symboli kultury żydowskiej w Olsztynie” (Żydowski dom..., 2002). Podobne określenia pojawiały się w różnych dziennikach.

Drugim miejscem upamiętniającym obecność Mendelsohna w Olsztynie jest jego rodzinny dom. Został on odnowiony jeszcze w latach dziewięćdziesiątych. Wówczas też architekt zaczął być promowany jako postać symbolicznie łącząca trzy kultury: polską, niemiecką i żydowską. Te powiązania postrzegane są jednak nie $\mathrm{w}$ odniesieniu do znaczeń narodowych czy pochodzenia etnicznego, ale jako przykład dziedzictwa, którego spadkobiercami czy, jak powiedziałby Jan Józef Lipski, „depozytariuszami” stają się dzisiejsi mieszkańcy

27 W późniejszych latach Mendelsohn został upamiętniony w projekcie „Dom Mendelsohna” — mającym na celu promowanie dialogu międzykulturowego (http://dommendelsohna.wordpress. com). 
Olsztyna. Taki sposób myślenia promuje nie tylko prasa, ale też publikacje popularnonaukowe, w których wiek XIX i początek XX przedstawiany jest jako czas współistnienia w Olsztynie trzech nacji i trzech kultur (Achremczyk, Ogrodziński 2003).

W podsumowaniu można powiedzieć, że $\mathrm{w}$ odstępie pięćdziesięciu lat zasadniczej zmianie uległ sposób przedstawiania przeszłości miasta, co wyraża się zarówno w usuwaniu, przywracaniu starych, jak i umieszczaniu nowych elementów w przestrzeni miejskiej. Zaniechano działań zmierzających do wyeliminowania symboli religijnych i wspomnienia o katolickiej instytucji jako założycielce Olsztyna. Zamiast tego po półwieczu można obserwować działania mające na celu nie tylko połączenie świeckich i religijnych symboli miasta, jakimi są nowy ratusz i katedra św. Jakuba, ale przede wszystkim wyeksponowanie ich jako tych mediów pamięci, które niosą przekaz o długich tradycjach miasta i związkach między przeszłością a teraźniejszością. Co więcej, w $2003 \mathrm{r}$. organizatorom uroczystości (w przeciwieństwie do ich poprzedników sprzed półwiecza) zależało już nie na podkreśleniu polskiej historii grodu, lecz jego „długiego trwania”, specyfiki i tradycji, niezależnie, czy można ją określić jako polską czy jako niemiecką. Eksponowanym wątkiem stała się też wielokulturowość Olsztyna i związane z nią bogate dziedzictwo historyczne i kulturowe stolicy Warmii.

Istotny okazał się też kontekst przedstawionych wyżej działań. Z prasowych wypowiedzi osób zajmujących się jubileuszem miasta wynika, iż w 2003 r. władze Olsztyna skupiły się głównie na upowszechnianiu turystyki i przedstawieniu miasta jako atrakcyjnego celu turystycznego. Działania zmierzające do upamiętnienia przeszłości miasta i wskazania na jego długie tradycje miały być elementem wspomagającym budowę wizerunku metropolii, nie zaś podstawowym zadaniem stawianym sobie przez władze lokalne, głównego organizatora obchodów jubileuszowych. Przyjęcie takiej strategii - jak sądzę miało wpływ zarówno na dobór prezentowanych treści, jak i na sposób ich przedstawienia.

Powyższe rozważania to jedynie przykład zastosowania koncepcji pamięci kulturowej oraz pojęć i kategorii analitycznych przedstawianych w pracach Jana i Aleidy Assmannów ${ }^{28}$. Pozwalają one wskazać przynajmniej niektóre możliwości i ograniczenia zastosowania propozycji niemieckich badaczy na gruncie polskich badań nad lokalną pamięcią kulturową.

Uczynienie podstawą analiz treści i sensów pamięci kulturowej łączonych $z$ mediami pamięci, takimi jak elementy przestrzeni miejskiej, pozwala nie

28 Szerszego opisania wymagają zagadnienia takie jak np. obecność i rola władz różnego szczebla w kształtowaniu lokalnej pamięci kulturowej czy mechanizmy zmian lokalnej pamięci kulturowej. 
tylko odwołać się do wielu różnorodnych, niekiedy bardzo odmiennych sposobów uobecniania przeszłości w teraźniejszości. Pozwala też prześledzić szereg zmian i procesów, jakim lokalna pamięć kulturowa uległa w odstępie kilkudziesięciu lat.

Co ważne, perspektywa Assmannów, czyli analiza figur wspomnień, a więc wyobrażeń o przeszłości funkcjonujących w danej grupie w danym czasie, nie zaś faktów historycznych ${ }^{29}$, pozwala na uchwycenie zmian i ciągłości interpretacji wydarzeń, postaci, symboli, na dokonanie analizy mechanizmów zmian postrzegania dawnych wydarzeń czy zjawisk, bez naruszania ważnego dla historyków zastrzeżenia co do nieporównywalności sytuacji z dwóch różnych okresów historycznych.

Oparcie badania na analizie mediów pamięci, takich jak różnego rodzaju elementy przestrzeni miejskiej pośrednio lub bezpośrednio nawiązujące do wybranych figur wspomnień, umożliwia uchwycenie złożoności i zmienności interpretacji tych samych symboli, postaci czy budowli na przestrzeni lat czy stuleci i uwzględnienie przy tym istniejących w danym czasie ram wspominania, a także rozpatrzenie procesów towarzyszących zmienności pamięci w odniesieniu do zmienności warunków politycznych, społecznych czy gospodarczych.

Zastosowanie koncepcji Assmannów nie pozwala jednak na odpowiedź, jak formowane odgórnie treści pamięci kulturowej i łączone z nimi sensy są przyjmowane przez członków społeczności lokalnej. Które jej elementy są akceptowane, a które odrzucane i $\mathrm{w}$ jakim stopniu. To zaś pociąga za sobą konieczność poszukiwania rozwiązań teoretycznych i metodologicznych nie uwzględnionych w propozycjach Assmannów.

Mimo tych zastrzeżeń należy zaznaczyć, iż system analityczny proponowany przez Assmannów może stać się inspirującą podstawą teoretyczną badań nad pamięcią zbiorową społeczności lokalnych. Pozwala prześledzić zmiany zachodzące w pamięci określanej przez Assmannów jako „kulturowa” cechującej bardzo różne społeczności (także lokalne) zarówno w długich okresach, jak i w odstępie kilkudziesięciu lat, wnioskować o procesach (ale i mechanizmach), jakim ta pamięć podlega, wpływie, jaki ma na kształtowanie tożsamości zbiorowej. Umożliwia też wykorzystanie założeń koncepcji i wypracowanego w jej ramach instrumentarium analitycznego do badań prowadzonych na gruncie różnych dyscyplin (historii, socjologii czy antropologii kulturowej) i na ich pograniczu. Stać się może podstawą studiów nad pamięcią społeczeństw współczesnych i tych funkcjonujących we wcześniejszych okresach historycznych, w bardzo różnych ustrojach politycznych i różnych kulturach.

29 Termin „fakty historyczne” rozumiem jako wizję wydarzeń, procesów czy zjawisk przedstawianą przez historyków na podstawie krytycznej analizy źródeł historycznych. 


\section{BIBLIOGRAFIA}

Achremczyk Stanisław, 2004, Olsztyn. Dzieje miasta, Wydawnictwo Dolnośląskie, Wrocław.

Achremczyk Stanisław, Ogrodziński Władysław (red.), 2003, Olsztyn 1353-2003, OBN-TN im. Wojciecha Kętrzyńskiego, Olsztyn.

Achremczyk Stanisław, Ogrodziński Władysław (red.), 2006, Olsztyn 1945-2005. Kultura i nauka, OBN, Olsztyn.

Assmann Aleida, 1999, Erinnerungsräume, Formen und Wandlungen des kulturellen Gedächtnisses, München.

Assmann Aleida, 2007, Geschichte im Gedächtnis. Von der individuellen Erfahrung zur öffentlichen Inszenizierun, Verlag C.H. Beck, München.

Assmann Aleida, 2009a, 1998 - Między historia a pamięcia, w: Magdalena Saryusz-Wolska (red.), Pamięć zbiorowa i kulturowa. Wspótczesna perspektywa niemiecka, Universitas, Kraków.

Assmann Aleida, 2009b, Przestrzenie pamięci. Formy i przemiany pamięci kulturowej, w: Magdalena Saryusz-Wolska (red.), Pamięć zbiorowa i kulturowa. Wspótczesna perspektywa niemiecka, Universitas, Kraków.

Assmann Aleida, 2009c, Pięć strategii wypierania ze świadomości, w: Magdalena Saryusz-Wolska (red.), Pamięć zbiorowa i kulturowa. Wspótczesna perspektywa niemiecka, Universitas, Kraków.

Assmann Jan, 2003, Pamięć zbiorowa i tożsamość kulturowa, „Borussia”, nr 29.

Assmann Jan, 2005, Das kulturelle Gedächtnis, Schrift, Erinnerung und politische Identität in frühen Hochkulturen, Verlag C.H. Beck, München.

Assmann Jan, 2008, Pamięć kulturowa. Pismo, zapamiętywanie i polityczna tożsamość w cywilizacjach starożytnych, tłum. Anna Kryczyńska-Pham, Wydawnictwa Uniwersytetu Warszawskiego, Warszawa.

Assmann Jan, 2009, Kultura pamięci, w: Magdalena Saryusz-Wolska, Pamięć zbiorowa $i$ kulturowa. Wspótczesna perspektywa niemiecka, Universitas, Kraków.

Berlińska Danuta, Madajczyk Piotr, 2008, Polska jako państwo narodowe, Historia i pamięć, Warszawa-Opole.

Borowik Andrzej (Władysław Gębik), 1953, Mikołaj Kopernik, „Słowo na Warmii i Mazurach", 21-22 lutego.

Chłosta Jan, 2003, Ludzie Olsztyna, Urząd Miasta, Olsztyn.

Czerwiński Ryszard, 2009, Olsztyn przestrzeń radości, El Set, Olsztyn.

Engelking-Boni Barbara, 2001, Zagłada i pamięć, IFiS PAN Warszawa.

Erll Astrid, 2009, Literatura jako medium pamięci zbiorowej, w: Magdalena Saryusz-Wolska (red.), Pamięć zbiorowa i kulturowa. Wspótczesna perspektywa niemiecka, Universitas, Kraków.

Grabowska Celina, 2003, Olsztyn na starych pocztówkach, Muzeum Warmii i Mazur, Olsztyn.

Huyssen Andreas, 2007, Po wojnie: Berlin jako palimpsest, w: Bartosz Korzeniewski (red.), Przemiany pamięci społecznej a teoria kultury, Instytut Zachodni, Poznań.

Jasiński Janusz, 2002, Przywróćmy obraz Matki Bożej oraz herb Olsztyna na Górnej Bramie, „Posłaniec Warmiński”, 1 września.

Jasiński Janusz, 2003, Legenda o św. Jakubie w Olsztynie, „Posłaniec Warmiński”, 22 czerwca. 
Kałążny Jerzy, 2007, Kategoria pamięci zbiorowej w badaniach literaturoznawczych, „Kultura Współczesna", nr 3.

Kopiczko Andrzej, 2003, Matka Boża z Wysokiej Bramy, „Posłaniec Warmiński”, 12 stycznia.

Korzeniewski Bartosz, 2005, Pamięć zbiorowa we wspótczesnym dyskursie humanistycznym, „Przegląd Zachodni”, nr 2.

Korzeniewski Bartosz, 2010, Transformacja pamięci, PTPN, Poznań.

Kula Marcin, 2004, Krótki raport o użytkowaniu historii, Wydawnictwo Naukowe PWN, Warszawa.

Kurczewska Joanna (red.), 2006, Oblicza lokalności. Różnorodność miejsc i czasu, IFiS PAN, Warszawa.

Kwiatkowski Piotr T., 2008, Pamięć zbiorowa społeczeństwa polskiego w okresie transformacji, Scholar, Warszawa.

Liżewska Iwona, 2006, Krajobraz po zmianach. O przestrzeni wyobrażonej realnej, „Borussia”, nr 39.

Liżewska Iwona, 2009, Przyjedź, odkryj, ocal od zapomnienia, „Borussia”, nr 46.

Liżewska Iwona, Knercer Wiktor (red.), 2004, „Zachowane - ocalone?”. O krajobrazie kulturowym i sposobach jego kształtowania, SWK Borussia, Olsztyn.

Orłowski Hubert, 2004, Literatura - tożsamość narodowa - pamięć kulturowa, w: Anna Wolff-Powęska, Dieter Bingen (red.), Polacy — Niemcy. Sąiedztwo z dystansu, Instytut Zachodni, Poznań.

Piechocki Stanisław, 1994, Dzieje olsztyńskich ulic, Remix, Olsztyn.

Piszcz, 2003, Wypowiedź Arcybiskupa Metropolity Warmińskiego ks. Dr Edmunda Piszcza, Dodatek do Gazety Olsztyńskiej, „Gazeta Olsztyńska”, 17 stycznia.

Protokół z posiedzenia..., 2003, Protokół z posiedzenia komisji konkursowej na plakat miejski „650 lat Olsztyna” w dniu 13 listopada 2003 roku, dokument przechowywany przez Wydział Kultury, Promocji i Turystyki Urzędu Miasta Olsztyna.

Rewers Ewa, 1999, Przestrzeń ponowoczesnego miasta: między logosem $i$ chora, w: Stefan Symotiuk, Grzegorz Nowak (red.), Przestrzeń w nauce wspótczesnej, t. 2, UMCS, Lublin.

Rzempołuch Andrzej, 2004, Architektura i urbanistyka Olsztyna 1353-1953, Od założenia miasta po odbudowe ze zniszczeń wojennych, Remix, Olsztyn.

Rzempoluch Andrzej, 2003, Olsztyna dzieje malowane, w: Dawny Olsztyn w malarstwie rysunku i grafice - katalog wystawy, Muzeum Warmii i Mazur, Olsztyn-Warszawa.

Saryusz-Wolska Magdalena, 2007, Strategie pamięci zbiorowej w przestrzeni miejskiej. Problemy Berlina po zjednoczeniu Niemiec, w: Barosz Korzeniewski (red.), Przemiany pamięci społecznej a teoria kultury, Instytut Zachodni, Poznań.

Saryusz-Wolska Magdalena (red.), 2009, Pamięć zbiorowa i kulturowa. Wspótczesna perspektywa niemiecka, Universitas, Kraków.

Stobiecki Rafał, 2007, Historiografia PRL. Ani dobra, ani mąra, ani piękna... ale skomplikowana, Trio, Warszawa.

Szacka Barbara, 2006, Pamięć zbiorowa - termin i pojęcie, w: Barbara Szacka, Czas przeszły - pamięć - mit, Scholar, Warszawa.

Tomkiewicz Ryszard, 2003, Życie codzienne mieszkańców powojennego Olsztyna 1945-1956, OBN, Olsztyn.

Traba Robert, 2005, Wschodniopruskość. Tożsamość regionalna i narodowa $w$ kulturze politycznej Niemiec, PTPN-ISP PAN, Poznań-Warszawa. 
Traba Robert, 2006, Historia - przestrzeń dialogu, Instytut Studiów Politycznych PAN, Warszawa.

Traba Robert, 2008, Wstęp do wydania polskiego. Pamięć kulturowa-pamięć komunikatywna. Teoria i praktyka badawcza Jana Assmanna, w: Jan Assmann, Pamięć kulturowa. Pismo, zapamiętywanie i polityczna tożsamość $w$ cywilizacjach starożytnych, tłum. Anna Kryczyńska-Pham, Wydawnictwa Uniwersytetu Warszawskiego, Warszawa.

Wakar Andrzej, 1971, Olsztyn 1353-1945, t. 1, Pojezierze, Olsztyn.

Wakar Andrzej, Wolski Bolesław, 1956, Sześć wieków Olsztyna, PWRN-WKFN, Olsztyn. Wóycicka Zofia, 2009, Przerwana żałoba. Polskie spory wokót pamięci nazistowskich obozów koncentracyjnych i zagłady 1944-1950, Trio, Warszawa.

Wysoka Brama..., 2003, Wysoka Brama z religijnym akcentem, „Gazeta Olsztyn”, dodatek do „Gazety Wyborczej”, 21 grudnia.

Zaremba Marcin, 2005, Komunizm, legitymizacja, nacjonalizm. Nacjonalistyczna legitymizacja wtadzy komunistycznej w Polsce, Trio, Warszawa.

Żydowski dom..., 2002, Żydowski dom przedpogrzebowy w ruinie, www.gazeta.olsztyn.pl [26.11.2002].

Żyłko Bogusław, 2010, Semiotyka kultury. Szkoła tartusko-moskiewska, słowo/obraz terytoria, Gdańsk.

Żytyniec Rafał, 2007, Pamięć o Prusach Wschodnich w literaturze niemieckiej $i$ polskiej po 1945 r., „Przegląd Zachodni”, nr 1.

Świat i My, „Głos Olsztyński”, 14 lutego 1953.

„Warmińskie Wiadomości Diecezjalne” 1953-1954, nr 1.

*

http://miasta.gazeta.pl/olsztyn/1,35187,2196013.html

http://olsztyn.kei.pl/index.php?option=com_content\&task = view\&id $=262 \& I t e m i d=$ 246

www.olsztyn.eu/fileadmin/katalogi_wydzialowe/kultura/wydawnictwa/symbole_pl. pdf.

\section{CULTURAL MEMORY AND CHANGES IN CITYSCAPE: AN ANALYSIS OF THE CELEBRATION OF THE ANNIVERSARY OF THE SETTLEMENT OF OLSZTYN FROM A PERSPECTIVE OF ALEIDA AND JAN ASSMANN'S CONCEPTS}

\section{Summary}

The author begins her article with a presentation of selected tenets of the concept of cultural memory proposed by Jan and Aleida Assmann, and with reviewing analytical categories used within the framework of this theory, including the following terms: cultural memory, memory figures, memory media, a palimpsest. These concepts form a theoretical and methodological basis for the upcoming analyses. The analyses con- 
tained in the article focus around the issues of change and continuity in the cultural memory of the inhabitants of Olsztyn, as exemplified by the transformations of Olsztyn's cityscape. The author considers two specific moments in the city's history: 2003, which marked the 650-anniversary of the city's settlement, and 1953, which marked the 600 -anniversary of the same event. Both these anniversaries were naturally celebrated in totally diverse political and ideological contexts. The article focuses not only on the transformations of cityscape, connected to the building of new monuments, plaques, and symbols, and to the renovation of selected buildings, but also on different ways of interpreting cityscape and architectural elements of which it consists in different periods. The conclusions from the analysis form a basis for pointing out several recommendations and limitations for using the Assmanns' concepts for researching local collective memory in Poland.

\section{Key words/słowa kluczowe}

Jan Assmann; Alejda Assmann; cultural memory / pamięć kulturowa; memory figures / figury wspomnień; memory media / media pamięci; Olsztyn 